\title{
Reversible Denaturierung des Proteins aus Tabakmosaikvirus
}

\author{
Von F. A. ANDERER \\ Aus dem Max-Planck-Institut für Virusforschung, Tübingen \\ (Z. Naturforschg. 14 b, 642-647 [1959] ; eingegangen am 5. August 1959)
}

\begin{abstract}
The protein of TMV is denaturated after extraction by phenol, precipitation with methanol and resolution in $0.1 \mathrm{M} \mathrm{NaOH}$ or $8 \mathrm{M}$ urea. The denaturated protein could be transformed to the native state. The following criteria were used for the differentiation between the denaturated and the native state: solubility in neutral aqueous medium, aggregation to regular viruslike rods, reconstitution to infectious virus with ribonucleic acid and the serological specificity.
\end{abstract}

Die Denaturierung von Proteinen verläuft in den meisten Fällen irreversibel. Bei einer Reihe von Proteinen jedoch wurde unter bestimmten Bedingungen auch ein reversibler Verlauf der Denaturierung festgestellt ${ }^{1}$. Es handelt sich hierbei im wesentlichen um Enzyme, wobei als Kriterium für eine Denaturierung und deren reversiblen Verlauf hauptsächlich das Verschwinden und Wiedererscheinen der enzymatischen Aktivität herangezogen wurde.

In der vorliegenden Arbeit wird untersucht, ob beim Protein des Tabakmosaikvirus (TMV) ebenfalls eine reversible Denaturierung möglich ist. Das TMV-Protein ist hierzu ein sehr geeignetes Untersuchungsobjekt, da verschiedene Möglichkeiten vorhanden sind, an Hand derer die Denaturierung, wie auch die Zurückbildung des nativen Zustands geprüft werden kann. Falls die Denaturierung reversibel verläuft, könnte man schließen, daß die räumliche Anordnung der Peptiduntereinheiten, d. h. die sekundäre und tertiäre Proteinstruktur, bereits durch die Primärstruktur, nämlich die Reihenfolge der Aminosäuren in der Peptidkette eindeutig bestimmt ist.

\section{Unterscheidung des nativen und denaturierten TMV-Proteins}

Es wurde früher von Sснramm und Mitarbb. ${ }^{2}$ gezeigt, daß nach schwach alkalischer Behandlung des Virus das Protein von der Nucleinsäure im nativen Zustand abgetrennt werden kann. Dieses Protein, dessen Mol.-Gew. sich zu ca. 100000 bestimmen ließ, wurde A-Protein genannt. Spätere Versuche zeigten, daß dieses A-Protein aus mehreren Untereinheiten besteht, für die neuerdings von Ansevin

1 Referiert nach W. Putnam, The Proteins IB, New York 1953, Academic Press.

2 G. Schramm, G. Schumacher u. W. Zillig, Z. Naturforschg. 10 b, 481 [1955]. und Lauffer ${ }^{3}$ durch direkte Messung der Sedimentations-Konstanten einer äußerst verdünnten Lösung ein Mol.-Gew. von 18000 bestimmt wurde. Der native Zustand des A-Proteins ist durch folgende Eigenschaften charakterisiert: Es ist in neutralem Medium leicht löslich. Ferner ist für das A-Protein kennzeichnend, daß es in schwach saurer Lösung zu stäbchenartigen Teilchen reaggregiert, die in ihrem Durchmesser und ihrer Röntgenstruktur mit dem nativen Virus übereinstimmen. Die Länge dieser Proteinstäbchen ist im Gegensatz zum Virus jedoch nicht definiert. Die Reaggregation erfolgt über mehrere Zwischenstufen. Als besonders typische Zwischenstufe wurden im Elektronenmikroskop scheibchenartige Partikel mit zentralem Loch festgestellt. Mit weiter fallendem $p_{\mathrm{H}}$-Wert lagern sich diese Scheibchen zu Stäbchen zusammen. Als zusätzliches Kriterium für den nativen Zustand ist die serologische Aktivität zu nennen. Es konnte gezeigt werden, daß die Bindungskapazität für die spezifischen Antikörper gegenüber dem nativen Virus nicht vermindert ist ${ }^{4}$. Außerdem wurde durch Fraenkel-Conrat und Mitarb. ${ }^{5}$ in den letzten Jahren gezeigt, daß sich natives TMV-Protein in Gegenwart von infektiöser Ribonucleinsäure (RNS) zu nucleinsäure-haltigen Viruspartikeln rekonstituieren läßt, die durch ihre Infektiosität und Struktur vom ursprünglichen Virus nicht zu unterscheiden sind.

Die Spaltung der im nativen Zustand bestehenden und die Ausbildung neuer unspezifischer Wasserstoffbrücken führt zur Denaturierung eines Proteins. Die ursprünglich vorhandene eindeutig bestimmte Konfiguration der Proteinmoleküle geht hierbei verloren und wird durch eine beliebig große

\footnotetext{
3 A. T. Ansevin u. M. A. Lauffer, Nature [London] 183 , 1601 [1959].

${ }^{4}$ P. Starlinger, Z. Naturforschg. 10 b, 339 [1955].

5 H. Fraenkel-Conrat u. B. Singer, Biochim. biophysica Acta [Amsterdam] 24, 540 [1957].
} 
Anzahl individueller Molekül-Konfigurationen ersetzt (Mirsky und Pauling) ${ }^{6}$. Eine Denaturierung in diesem Sinne kann durch extreme Temperaturänderungen und $p_{\mathrm{H}}$-Verschiebungen, ferner durch die Verwendung von Wasserstoffbrücken bildenden organischen Verbindungen unter geeigneten Bedingungen erzielt werden. Eine Spaltung von kovalenten Bindungen führt zur Zerstörung oder zumindest zur chemischen Veränderung von Proteinmolekülen und soll daher im folgenden nicht als Denaturierung bezeichnet werden.

Hiernach bleibt die Primärstruktur (Aminosäuresequenz) eines Proteins bei der Denaturierung unverändert. Der Verlust der biologischen Aktivität und der serologischen Spezifität sowie die verminderte Löslichkeit eines denaturierten Proteins resultieren aus der Änderung der eindeutig bestimmten Konfiguration im nativen Zustand. Auf die gleiche Ursache ist die erhöhte Reaktivität von funktionellen Gruppen in denaturierten Proteinen und die bessere Zugänglichkeit für proteolytische Enzyme zurückzuführen.

Beim TMV wurde die Hitzedenaturierung durch Lauffer und Price ${ }^{7}$ eingehend studiert. Um Störungen durch die Nucleinsäure zu vermeiden, wurden in der vorliegenden Arbeit Untersuchungen an reinem Protein durchgeführt. In der vorangegangenen Arbeit ${ }^{8}$ sind die Eigenschaften eines nucleinsäure-freien denaturierten Proteins aus TMV beschrieben, das nach der Methode von Schuster, Schramm und Zillig ${ }^{9}$ durch Phenolextraktion gewonnen wurde. Dieses Protein ist in Wasser äußerst schlecht löslich, löst sich aber ohne weiteres in verdünntem Alkali. Es bedarf jedoch eines ziemlich hohen $p_{\mathrm{H}}$-Wertes, um die intermolekularen Wasserstoffbrücken zu sprengen. Eine Lösung der monomeren Peptiduntereinheiten des TMV-Proteins konnte erst in $0,1-n . \mathrm{NaOH}\left(0,8 \%\right.$ Protein, $\left.p_{\mathrm{H}} 13,0\right)$ erhalten werden. Durch Messung der Sedimentations- und Diffusionskonstanten wurde das Mol.Gew. der kleinsten denaturierten Peptiduntereinheit zu $18800 \pm 10 \%$ bestimmt. Außerdem kann dieses denaturierte Protein in 8- $m$. Harnstofflösung oder durch Erhitzen einer neutralen, wäßrigen Suspen-

6 A. E. Mirsky u. L. Pauling, Proc. nat. Acad. Sci. USA 22, 439 [1936].

7 M. A. Lauffer u. W. C. Price, J. biol. Chemistry 133, 1 [1940].

8 F. A. Anderer, Z. Naturforschg. 14 b, 24 [1959].

9 H. Schuster, G. Schramm u. W. Zilitg, Z. Naturforschg. sion auf $60-80{ }^{\circ} \mathrm{C}$ gelöst werden. In alkalischer Lösung, in der die monomere Peptiduntereinheit vorliegt, ist der Verlust der räumlichen Anordnung der Peptidketten (Tertiärstruktur) eindeutig. Auch die Faltung innerhalb der Peptidkette (Sekundärstruktur), die im nativen Zustand besonders durch Wasserstoffbrücken gebildet wird, dürfte unter den gewählten Bedingungen größtenteils aufgehoben sein. Ferner konnte gezeigt werden, daß nach der Denaturierung beide in der Peptiduntereinheit vorkommenden Lysinreste der Dinitrophenylierung zugänglich waren ${ }^{10}$, während bei den bisherigen Untersuchungen am nativen Protein ${ }^{11,12}$ nur ein Lysylrest erfaßt werden konnte. Im Gegensatz zum nativen Virus, das von proteolytischen Enzymen nicht merklich angegriffen wird, ist das mit Phenol denaturierte Protein der Spaltung mit den verschiedensten Proteasen sehr gut zugänglich. Endgruppenbestimmungen, die mit diesem Präparat durchgeführt wurden, zeigten, daß bei der Denaturierung mit Phenol keine Peptidbindungen gespalten werden.

Alle diese Befunde sowie die Methode der Präparation sprechen eindeutig dafür, daß das durch Phenolextraktion gewonnene Protein nach Harnstoff-, Alkali- oder Hitzebehandlung weitgehend denaturiert ist.

\section{Versuche zur Renaturierung}

Das mit Phenol denaturierte TMV-Protein kann durch verdünntes Alkali, konzentrierte Harnstofflösung oder durch Erhitzen einer wäßrigen Suspension auf $60-80^{\circ} \mathrm{C}$ und Zufügen von verdünntem Alkali bis $p_{\mathrm{H}} 7,5$ in Lösung gebracht werden.

Es ist bisher nicht gelungen, durch Ansäuern der alkalischen Proteinlösung mit verdünnter $\mathrm{HCl}$ auf $p_{\mathrm{H}} 6,0$ stäbchenförmige Protein-Aggregate zu erhalten. Wahrscheinlich verhindert die lokale Übersäuerung der Lösung hierbei die Einstellung der nativen Konfiguration. Auch wenn über einen Zeitraum von mehreren Tagen das $p_{\mathrm{H}}$ langsam von 13,0 auf 6,3 gesenkt wurde, konnten im Elektronenmikroskop nur unregelmäßige Aggregate und kaum Stäbchen

11 b, 339 [1956] ; A. Gierer u. G. Schramm, 11 b, 138 [1956].

10 F. A. Anderer, Z. Naturforschg. 14 b, 363 [1959].

11 H. Fraenkel-Conrat u. B. Singer, J. Amer. chem. Soc. 76, 180 [1953].

12 L. K. Ramachandran, Biochim. biophysica Acta [Amsterdam] 32, 557 [1959]. 
beobachtet werden. Die Reaggregation des denaturierten Proteins zu stäbchenförmigen Partikeln, ausgehend von der alkalischen Lösung, gelingt jedoch, wenn die Alkalität möglichst schnell vermindert und durch Phosphatpuffer von $p_{\mathrm{H}} 6,2$ bis 5,9 ersetzt wird. Für die Einstellung des Aggregations-Gleichgewichts genügt eine Dialysendauer von 20 bis 30 Stunden. Die elektronenoptischen Aufnahmen zeigen im wesentlichen Scheibchen mit dem Durchmesser der nativen Virusteilchen, die ein zentrales Loch besitzen, sowie kürzere Stäbchen bis zur halben Länge eines Viruspartikels (Abb. $\left.1^{*}\right)$. Wird diese Proteinlösung weiter gegen $10^{-3}$ bis $10^{-4}-m$. Essigsäure salzfrei dialysiert, so lagern sich mit fallendem $p_{\mathrm{H}^{-}}$-Wert die scheibchenförmigen Partikel zu längeren Stäbchen zusammen. Die Dialyse gegen verdünnte Essigsäure hat jedoch den Nachteil, daß das aggregierte Protein manchmal ausfällt. Es ist daher statt der verdünnten Essigsäure die Verwendung eines flüchtigen Puffers vorzuziehen, wobei sich $5 \cdot 10^{-3}-m$. Ammonacetat von $p_{\mathrm{H}} 5,5$ bis 5,7 besonders bewährte. Auf den elektronenoptischen Aufnahmen, von denen ein Beispiel in Abb. 2 gegeben ist, sieht man Stäbchen, mit dem gleichen Durchmesser wie natives Virus, die jedoch in ihrer Länge variabel sind. Da die elektronenoptischen Präparate nicht gewaschen sind, enthalten sie alle in der Lösung vorkommenden Proteinteilchen. Sie sind daher ein guter Maßstab für die Ausbeute an renaturiertem Protein. Wie Abb. 2 zeigt, sind praktisch keine unregelmäßigen Aggregate zu bemerken.

Renaturierungs-Versuche, ausgehend von einer Lösung des denaturierten Proteins in 8- $m$. Harnstoff und $0,2-m$. Phosphatpuffer, führten ebenfalls nicht zum nativen Protein, wenn die Harnstoffkonzentration über einen Zeitraum von mehreren Tagen langsam auf null gesenkt wurde. Es erwies sich als vorteilhaft, den Harnstoff möglichst schnell gegen ein großes Volumen Puffer herauszudialysieren, wobei die Verwendung von 0,02-m. Phosphatpuffer $p_{\mathrm{H}} 5,9-6,2$ wiederum besonders geeignet war. Als native $Z$ wischenstufen erscheinen die scheibchenförmigen Partikel, die nach Dialyse gegen $10^{-3}$. bis $10^{-4}-m$. Essigsäure oder $5 \cdot 10^{-3}-m$. Ammonsulfat, $p_{\mathrm{H}} 5,5$ bis 5,7 Proteinstäbchen bilden.

Die Überführung des denaturierten Proteins in den nativen Zustand unter Benützung der beiden beschriebenen Methoden gelingt bei $4{ }^{\circ} \mathrm{C}$, wie auch bei Zimmertemperatur, in Ausbeuten zwischen 70

* Abb. 1 u. 2 s. Tafel S. 630 b. und 100 Prozent. Etwas geringere Ausbeuten (50 bis $80 \%$ ) erhält man, wenn eine wäßrige Suspension des denaturierten Proteins auf 60 bis $80{ }^{\circ} \mathrm{C}$ erhitzt und solange verdünntes Alkali zugefügt wird, bis das Protein in Lösung geht. Hierbei wird ein $p_{\mathrm{H}}$-Wert von 7,0 bis 7,5 meistens nicht überschritten. Nach Abkühlen wird diese Proteinlösung in analoger Weise zu den oben angeführten Methoden gegen 0,02-m. Phosphatpuffer, $p_{\mathrm{H}} 5,9-6,2$, und dann gegen verdünnte Essigsäure oder Ammonacetatpuffer dialysiert. Es zeigen sich auch hier die schon beschriebenen nativen Zwischenstufen und schließlich die stäbchenförmigen Proteinaggregate.

Um die Struktur des renaturierten Proteins zu überprüfen, wurde die Antikörperbindungs-Kapazität von nativem Virus, renaturiertem und regellos aggregiertem Protein (letzteres durch direkte Neutralisation einer alkalischen Proteinlösung mit verdünntem $\mathrm{HCl}$ gewonnen) bei $p_{\mathrm{II}} 7$ miteinander verglichen. Eine abgemessene Menge TMV-Antiserum wurde mit äquivalenten Mengen (bezogen auf ProteinStickstoff) der drei Antigene absorbiert, das entstandene Präzipitat abzentrifugiert und der jeweilige Überschuß an Antiserum mit TMV zurücktitriert. Die Ergebnisse sind in Abb. 3 graphisch dargestellt.

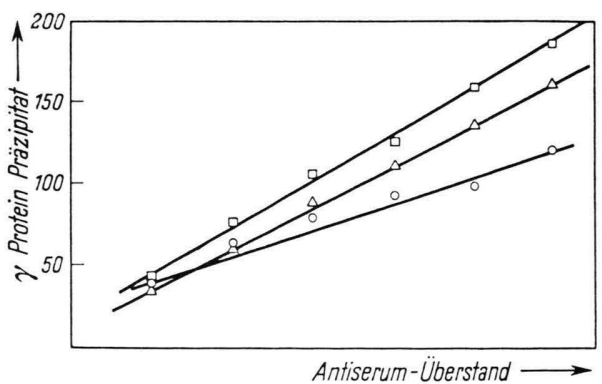

Abb. 3. Quantitative Präzipitinkurven des Antiserum-Überschusses mit TMV als Antigen nach partieller Absorption von TMV-Antiserum durch folgende Antigene: $\bigcirc$ TMV, $\triangle$ renaturiertes TMV-Protein, $\square$ regellos aggregiertes TMV-Protein.

Hieraus läßt sich ablesen, daß TMV am meisten und das regellos aggregierte Protein am wenigsten Antikörper aus einem TMV-Antiserum zu binden vermag, während die Antikörperbindungs-Kapazität des renaturierten Proteins zwischen diesen beiden Antigenen liegt.

Der günstige Verlauf der reversiblen Denaturierung ließ die Frage offen, ob das reaggregierte Protein noch befähigt ist, im Gemisch mit TMV-RNS infektiöse Virusteilchen zurück zu bilden. Unter Benützung von nativen Proteinpräparaten ist die Virus- 
rekonstitution bereits einigen Arbeitsgruppen ${ }^{5,13}$ gelungen. Für die vorliegenden Versuche wurden für die Virusrekonstitution im wesentlichen die Versuchsbedingungen von $\mathrm{H}_{\mathrm{ART}}{ }^{13}$ mit einigen Abänderungen übernommen. Die alkalische Lösung des denaturierten Proteins wurde zuerst bei $p_{\mathrm{H}} 5,9$ zu Stäbchen aggregiert und dann bei $p_{\mathrm{H}} 7-7,2$ mit $5-6 \% \mathrm{TMV}$ RNS gemischt. Diese Mischung wurde während einer Stde. mit verdünnter Phosphorsäure auf $p_{\text {II }} 5,9$ eingestellt und weitere $30 \mathrm{Stdn}$. bei Zimmertemperatur stehen gelassen. Nach anschließender Ultrazentrifugation bei $p_{\mathrm{H}} 9,0$ konnte ein Sediment isoliert werden, das größtenteils aus rekonstituiertem Virus bestand, jedoch Beimengungen an aggregiertem Protein enthielt. Die Infektiosität dieses Sediments war sehr gering, Kontrollexperimente mit einem Gemisch von nativem Virus und renaturiertem Protein zeigten, daß ein Überschuß von Protein die Infektiosität wesentlich verringert. Es ist daher wichtig, das rekonstituierte Virus möglichst vom überschüssigen Protein zu trennen. Dies gelingt durch wiederholte Ultrazentrifugation aus ionenarmen, möglichst alkalischem Medium. Das hierbei erhaltene Sediment II zeigte im UV-Spektrophotometer ein Absorptionsverhältnis wie natives Virus $(260 \mathrm{~m} \mu / 280 \mathrm{~m} \mu$ $=1,14-1,16)$, so daß eine wiederholte Zentrifugation unter den gleichen Bedingungen meist unterbleiben konnte. Eine anschließende Extraktion der wäßrigen Lösung des Sediments mit Arcton 63 brachte jedoch noch eine weitere Erhöhung der Infektiosität.

Die zu den Rekonstitutions-Versuchen benützte RNS hatte eine um den Faktor $2 \cdot 10^{3}$ geringere Infektiosität als natives Virus. Die Absolutausbeute an rekonstituiertem Virus, bezogen auf die eingesetzte Menge Protein und RNS, betrug zwischen 20 und 50 Prozent. Dieses Material zeigte, bezogen auf eine äquivalente Menge RNS, eine um den Faktor $4 \cdot 10^{2}$ höhere Infektiosität und $15-20 \%$ der Infektiosität des nativen Virus. Die Infektiosität des rekonstituierten Virus ist gegen Ribonuclease stabil.

\section{Diskussion der Ergebnisse}

Eine grundsätzliche Frage ist, inwieweit die Denaturierung des benützten Proteinpräparats als vollständig bezeichnet werden kann, d. h. ob alle im nativen Zustand bestehenden Wasserstoffbrücken wäh-

13 R. G. Hart u. J. D. Sмith, Nature [London] 178, 739 [1956]. rend des Denaturierungsvorganges gelöst wurden. Die Verwendung der stärksten bekannten Denaturierungsmittel, wie Phenol, Methanol, Harnstoff, Alkali oder Hitzebehandlung, spricht dafür, daß die Sekundärstruktur, d. h. die Faltung der Peptidkette weitgehend aufgelöst ist. Die Mol.-Gew.-Bestimmung des denaturierten Proteins in alkalischer Lösung zeigt, daß die tertiäre Struktur eindeutig verloren gegangen ist. Bei verschiedenen Präparationen von denaturiertem Protein traten jedoch Anzeichen für graduelle Unterschiede in der Denaturierung auf. Manche Proteinpräparate ließen sich besser aus alkalischer Lösung, andere wiederum besser aus Harnstofflösung renaturieren. Es ist daher zweifelhaft ob sämtliche nativen Wasserstoffbrücken bei der angeführten Methode der Denaturierung gesprengt werden. Es kann jedoch angenommen werden, daß die Denaturierung in jedem Falle sehr weitgehend ist.

Der einleuchtendste Beweis, daß der native $\mathrm{Zu}$ stand wieder hergestellt worden ist, liegt in dem Befund, daß sich die regelmäßige Struktur des ProteinHohlzylinders zurückgebildet hat. Dies ist nur möglich, wenn die ursprüngliche räumliche Konfiguration sich wieder eingestellt hat. Im gleichen Sinne spricht die spezifische Rekonstitution mit RNS zu infektiösen Viruspartikeln. Die Stabilität der rekonstituierten Virusteilchen bei $p_{\mathrm{H}} 9$, bei dem die Proteinaggregate schon wieder zu A-Protein zerfallen sind, beweist, daß tatsächlich eine feste Bindung zwischen RNS und Protein erfolgt ist. Ferner zeigt die Stabilität gegen Ribonuclease, daß die RNS vollständig vom Protein umhüllt ist und keine Proteinlücken vorkommen, an denen das Enzym angreifen kann. Die serologischen Untersuchungen lassen erkennen, daß die AntikörperBindungskapazität des renaturierten Proteins der des nativen Zustands ziemlich angenähert ist. Zwar wird sie nicht vollständig erreicht, was wohl daran liegt, daß bei neutralem $p_{\mathrm{H}}$ noch keine Proteinstäbchen gebildet sind, sondern wesentlich kleinere Partikel von der Größe der Scheibchen mit zentralem Loch oder darunter. Aus dem nahezu quantitativen Verlauf der reversiblen Denaturierung ist zu entnehmen, daß das TMV-Protein bei der Phenolextraktion in seiner chemischen Struktur nicht verändert wird. Ferner ergibt sich aus der quantitativen Reaggregation der Peptiduntereinheit zu stäbchenförmigen Polymerisaten, daß alle Peptiduntereinheiten identisch sind, oder sich allenfalls nur durch lokal begrenzte Fehlstellen unterscheiden, die die Peptid- 
faltung im wesentlichen nicht beeinflussen. Die reversible Denaturierung des TMV-Proteins macht es sehr wahrscheinlich, daß zur spezifischen Faltung von Polypeptidketten keinerlei Enzyme oder Matrizen benötigt werden. Die eindeutig bestimmte Konfiguration der Proteinmoleküle im nativen Zustand ist durch die Aminosäuresequenz und durch die maximalen Bindungsenergien der von den einzelnen Aminosäuren ausgehenden Wasserstoffbrücken gegeben.

Auch bei anderen Proteinen sollte daher eine reversible Denaturierung grundsätzlich möglich sein, sofern hierbei keine chemische Veränderung der Proteinmoleküle eintritt. Bei Proteinen mit Disulfidbrücken besteht jedoch die Schwierigkeit, daß während der Denaturierung die von SANGER ${ }^{14}$ gefundene Transsulfidierungs-Reaktion eintritt und dadurch eine direkte Renaturierung verhindert wird. Beim TMV liegen die Verhältnisse besonders günstig, als je Peptiduntereinheit nur ein Cysteinrest vorkommt und Disulfidbrücken nicht nachweisbar sind.

Es besteht ferner die Möglichkeit, daß während des Renaturierungs-Vorgangs intermediäre Wasserstoff-Brücken ausgebildet werden, die nicht dem nativen Zustand entsprechen. Diese können auch im neutralen Medium so stabil sein, daß sie die Bildung der nativen Konfiguration verhindern. Beim TMVProtein ist dies bei den beschriebenen Bedingungen offensichtlich nicht der Fall.

Die Virusrekonstitution in vitro, ausgehend von den monomolekularen Lösungen der Peptiduntereinheit und der RNS, macht es daher wahrscheinlich, daß der Mechanismus der Virussynthese in der Zelle auf das Problem der Synthese der monomeren RNS und Peptiduntereinheit beschränkt ist. Die Ausbeuten bei der Virusrekonstitution sind in erster Linie von der Präparation der RNS und des Proteins abhängig. Von Gierer ${ }^{15}$ wurde gezeigt, daß nur der intakte RNS-Strang vom Mol.-Gew. $2 \cdot 10^{6}$ infektiös ist. Selbst eine geringe chemische Veränderung dieses Moleküls führt zum Verlust der Aktivität (Schuster, Schramm ${ }^{16}$ ).

Bei der Isolierung der RNS läßt es sich nicht vermeiden, daß ein Teil der Moleküle gespalten wird und daher nicht mehr infektiös ist. Diese RNSBruchstücke führen bei der Rekonstitution zu inakti-

14 F. Sanger u. A. P. Ryle, Biochem. J. 60, 535 [1955].

15 A. Gierer, Z. Naturforschg. 13 b, 485 [1958].

16 H. Schuster u. G. Schramm, Z. Naturforschg. 13 b, 697 [1958]. ven Nucleoproteiden, die die spezifische Infektiosität des Präparats wesentlich verringern. Ferner ist aus den Kontrollversuchen $\mathrm{zu}$ ersehen, daß selbst ein geringer Überschuß an adsorbiertem Protein die Infektiosität herabsetzen kann. Es liegt jedoch im Bereich der Möglichkeit, durch Verfeinerung der Methodik und sorgfältiger Präparation der RNS noch bessere Ausbeuten und eine höhere Infektiosität zu erreichen, wie sie z. T. schon von FraenkelConrad $^{17}$ erzielt worden ist. Dahingehende Untersuchungen sind im Gange.

\section{Methoden}

A usgangsmaterial

Sämtliche Untersuchungen wurden mit dem TMVStamm vulgare durchgeführt. Die RNS wurde durch Phenolextraktion des Proteins aus einer 6-proz. TMV. Lösung $p_{\mathrm{H}} 6,0$ gewonnen ${ }^{9}$. Das Protein wurde nach einer früher beschriebenen Vorschrift dargestellt ${ }^{8}$. Hierbei wird das Protein unter Zugabe von etwas festem Natrium- oder Ammoniumacetat mit Methanol ausgefällt und einige Male mit Methanol und anschließend mit Äther gewaschen. Die Präparate wurden teilweise bis zu 5 Monate im lufttrocknen Zustand bei $4{ }^{\circ} \mathrm{C}$ aufbewahrt. Für die Einstellung der gewünschten $p_{\mathrm{H}}$-Werte wurde der Jacobsen-Leonis-Autotitrator der Firma Radiometer Copenhagen benützt.

\section{Methoden zur Renaturierung}

Die Überführung des denaturierten luft-trocknen Proteins in den nativen Zustand gelingt auf folgende drei verschiedene Arten:

a) durch Alkali: $10 \mathrm{mg}$ lufttrockenes Protein wurden in $2 \mathrm{ml} 0,1-m$. NaOH gelöst und mit Wasser auf $5 \mathrm{ml}$ verdünnt. Diese Lösung wurde $20-30 \mathrm{Stdn}$. bei $4^{\circ}$ oder $20^{\circ} \mathrm{C}$ gegen $2 l \quad 0,02-m$. Phosphatpuffer $p_{\mathrm{H}} 5,9$ dialysiert. In dieser Zeit wurde das Außendialysat 3- bis 4-mal gewechselt. Anschließend wurde 1-2 Stdn. bei $4{ }^{\circ} \mathrm{C}$ gegen $10^{-3}$ bis $10^{-4}-m$. Essigsäure dialysiert und diese Lösung nach Verdünnen zu elektronenmikroskopischen Untersuchungen benützt. Ein während der Dialyse gegen verdünnte Essigsäure manchmal erscheinender Niederschlag läßt sich durch Zufügen von verdünntem Ammoniak wieder in Lösung bringen. Um ein Ausfallen des aggregierten Proteins zu vermeiden, ist es daher vorzuziehen, statt gegen $10^{-3}-m$. Essigsäure gegen $5 \cdot 10^{-3}-m$. Ammoniumacetat $p_{\mathrm{H}} 5,5$ bis $5,7 \mathrm{zu}$ dialysieren. Die elektronenmikroskopischen Präparate dieser Lösung brauchen ebenfalls nicht gewaschen zu werden.

b) durch Harnstoff. $10 \mathrm{mg}$ lufttrockenes Protein

17 R. Haschemeyer, B. Singer u. H. Fraenkel-Conrat, Proc. nat. Acad. Sci. USA 45, 313 [1959]. 
wurden in $5 \mathrm{ml}$ einer Lösung, die 8-m. Harnstoff und $0,02-m$. Phosphatpuffer von $5,9-6,2 p_{\mathrm{H}}$ enthielt, gelöst. Anschließend wurde wie unter a gegen Phosphatpuffer und dann gegen $10^{-3}-m$. Essigsäure oder $5 \cdot 10^{-3}-m$. Ammoniumacetat-Puffer $p_{\mathrm{H}} 5,5$ bis 5,7 dialysiert.

c) durch Hitzebehandlung. $10 \mathrm{mg}$ lufttrockenes Protein wurden in $5 \mathrm{ml}$ Wasser suspendiert und in einem Wasserbad auf $60-80{ }^{\circ} \mathrm{C}$ erwärmt. Durch Zufügen von wenig $0,02-n$. NaOH geht das Protein in Lösung. Hierbei wurde ein $p_{\mathrm{H}}$-Wert von 7,0 bis 7,5 erreicht. Nach Abkühlen bleibt das Protein in Lösung. Diese Lösung wurde dann wie unter a gegen Phosphatpuffer und anschließend gegen verdünnte Essigsäure oder Ammoniumacetat-Puffer $p_{\mathrm{H}} 5,5$ bis 5,7 dialysiert.

\section{Elektronenmikroskopie}

Für die elektronenoptischen Aufnahmen diente das elektrostatische Elektronenmikroskop der Firma AEG Zeiss. Die verdünnten Lösungen wurden auf Kollodiumfolien eingetrocknet, salzhaltige Präparate wurden mit 0,001-m. Essigsäure gewaschen, salzfreie Präparate ohne Waschen mit Pt-Rh unter einem Winkel von ca. $25^{\circ} \mathrm{C}$ bedampft.

\section{Serologische Versuche}

Zum Vergleich der Antikörperbindungs-Kapazität wurde eine 0,3-proz. Proteinlösung in 0,02-n. $\mathrm{NaOH}$ $30 \mathrm{Stdn}$. bei $4{ }^{\circ} \mathrm{C}$ gegen $0,02-m$. Phosphatpuffer $p_{\mathrm{H}} 6,0$ dialysiert und dann mit verdünnter Natronlauge auf $p_{\mathrm{H}} 7$ titriert (renaturiertes Protein). Das regellos aggregierte Protein wurde durch Titration der alkalischen Proteinlösung mit $0,2-n$. $\mathrm{HCl}$ auf $p_{\mathrm{H}} 7,0$ gewonnen.

Jeweils 1,2 mg Protein-N vom renaturierten, regellos aggregierten Protein und vom TMV wurden in separaten Ansätzen zu $3 \mathrm{ml}$ TMV-Antiserum pipettiert. Alle Ansätze wurden mit 0,9-proz. Natriumchlorid-Lösung auf das gleiche Volumen gebracht. Nach 6-stdg. Stehen bei Zimmertemperatur wurden die entstandenen Präparate abzentrifugiert. Die Menge des hierbei nicht gebundenen Antiserums in den verschiedenen Ansätzen wurde an Hand von quantitativen Präzipitin-Kurven der entsprechenden Antiserum-Überstände mit TMV als Antigen verglichen.

\section{Virus-Rekonstitution}

Eine alkalische Lösung, die $0,3 \%$ denaturiertes Protein enthielt, wurde, wie oben beschrieben, bei $p_{\mathrm{H}} 5,9$ und $4{ }^{\circ} \mathrm{C}$ zu Stäbchen aggregiert und $1-2 \mathrm{Stdn}$. gegen $10^{-3}$ bis $10^{-4}-m$. Essigsäure oder gegen $5 \cdot 10^{-3}-m$. Ammoniumacetat-Puffer $p_{\mathrm{H}} 5,5$ bis 5,7 dialysiert. Es ist darauf zu achten, daß das gewonnene Präparat bei der elektronenoptischen Untersuchung mit einer Stäbchenausbeute mit möglichst mehr als $90 \%$ vorliegt. Dieses Präparat wird mit Wasser zu einer 0,1-proz. Proteinlösung verdünnt und mit $0,4-m . \mathrm{Na}_{2} \mathrm{HPO}_{4}$ und $0,1-n . \mathrm{NaOH}$ auf $0,02-m$. Phosphat und $p_{\mathrm{H}} 7,0$ bis 7,2 gebracht. $\mathrm{Zu}$ 100 Teilen Protein gibt man $5-6$ Teile RNS (0,2-proz. Lösung in 0,02-m. Phosphat $\left.p_{\mathrm{H}} 6,0-6,5\right)$, die durch Phenolextraktion aus einer 5-proz. TMVLösung gewonnen wurde. Während einer Stde. wird dann bei Zimmertemperatur mit verdünnter Phosphorsäure das $p_{\mathrm{H}}$ der Lösung auf $p_{\mathrm{H}} 5,9$ gesenkt und weitere $30 \mathrm{Stdn}$. bei Zimmertemperatur stehen gelassen. Vor der Ultrazentrifugation (Spinco $30000 \mathrm{U} / \mathrm{min}$, 50 min bei $25 \mathrm{ml}$ Becherfüllung) wird mit $0,5-n$. $\mathrm{NaOH}$ $p_{\mathrm{H}} 9$ eingestellt. Das Sediment wird in Wasser aufgenommen und vor der zweiten Sedimentation auf $10^{-4}-m$. NaOH gebracht. Dieses Sediment wurde ebenfalls in Wasser aufgenommen und mit dem 10. Teil des Volumens Arcton 63 ausgeschüttelt. Die Phasen lassen sich durch Zentrifugation bei $4000 \mathrm{U} / \mathrm{min}$ (15 min) leicht trennen. Die überstehende wäßrige Phase wurde für die Aktivitätsbestimmung benützt. Für die Infektiositätsteste wurden jeweils 5 Pflanzen Nicotiana glutinosa mit je 5 Blättern verwendet. Zum Nachweis der Hemmung des TMV durch überschüssiges A-Protein wurden $10 \mathrm{mg}$ TMV (0,3-proz. Lösung) + $5 \mathrm{mg}$ reaggregiertes A-Protein (0,3-proz. Lösung) in 0,02-m. Phosphat $p_{H} 7,2$ gemischt und $20 \mathrm{Stdn}$. gegen $0,02-m$. Phosphat $p_{\mathrm{H}}$ 5,9 dialysiert. Anschließend wurde wie beim Hauptversuch durch zweimalige Sedimentation und Arcton-Behandlung aufgearbeitet. Die Infektiosität des hierbei erhaltenen Sediments wurde vor und nach Behandlung mit Arcton 63 auf Nicotiana glutinosa ausgetestet und mit nativem TMV verglichen.

Herrn Prof. Dr. Schramm danke ich für Förderung der Arbeit und anregende Diskussionen, Herrn G. BERGER für die elektronenoptischen Aufnahmen, Herrn Dr. P. Vogt für die serologische Beratung, Frl. A. KLEIH für die Pflanzenteste und Herrn D. Handschur für technische Assistenz. Der De u t s chen For s chungs$\mathrm{g}$ e m e in s c h a f t danke ich für eine Sachbeihilfe. 